\title{
Tuturan Ekpresif dalam Debat CAPRES Republik Indonesia 2019
}

\author{
Ika Purwaningsih*, Ratu Wardarita, Siti Rukiyah \\ Magister Pendidikan Bahasa Indonesia, Universitas PGRI Palembang, Indonesia \\ *ikapurwaningsih037@gmail.com
}

\begin{abstract}
Abstrak
Penelitian ini bertujuan mendesfkripsikan fungsi tuturan ekspresif dalam debat calon presiden (CAPRES) RI 2019. Penelitian ini menggunakan metode deskriptif kualitatif. Data penelitian ini bersumber dari debat CAPRES RI 2019 pada Youtube Channel CNN Indonesia. Dalam menganalisis data, peneliti menggunakan metode padan intralingual. Adapun langkah-langkahnya ialah sebagai berikut: (1) Mengubah data ke bentuk teks, (2) Mengidentifikasi tuturan ekspresif yang terdapat dalam debat, (3) Mengklasifikasikan data berdasarkan fungsi tuturan ekspresif, (4) Melakukan analisis data, dan (5) Menyimpulkan hasil analisis. Berdasarkan hasil penelitian terdapat 81 data tuturan meliputi 6 data tuturan ucapan selamat, 32 data tuturan terima kasih, 12 data tuturan mengkritik, 3 data tuturan mengeluh, 9 data tuturan menyalahkan, 1 data tuturan, memuji, 9 data tuturan meminta maaf, dan 9 data tuturan menyindir.
\end{abstract}

Kata kunci: debat CAPRES RI 2019, ekspresif, tuturan.

\section{Identitas Artikel:}

Purwaningsih, I., Wardarita, R., \& Rukiyah, S. (2022). Tuturan Ekpresif dalam Debat CAPRES Republik Indonesia 2019. Jurnal Ilmu Pendidikan (JIP) STKIP Kusuma Negara, 13(2), 151162.

\section{PENDAHULUAN}

Bahasa merupakan alat komunikasi yang digunakan oleh manusia. Tanpa bahasa, manusia akan sulit untuk berkomunikasi satu sama lain. Chaer (2010) menyatakan penutur menggunakan bahasa sebagai alat komunikasi atau berinteraksi dalam suatu tuturan. Bahasa yang baik dan benar tentu saja muncul dari pribadi yang baik (Saripudin, 2018). Berbicara mengenai penggunaan bahasa tentu tidak akan terlepas dari siapa yang berbicara, siapa yang diajak berbicara, apa yang dibicarakan, dan dimana berbicara (Indrawati, 2008). Lebih lanjut, penggunaan bahasa tidak bisa diabaikan karena bahasa merupakan perilaku sosial yang dipakai dalam komunukasi.

Berdasarkan wujudnya bahasa dibagi menjadi dua yaitu bahasa tulis dan bahasa lisan. Tuturan adalah salah satu wujud bahasa lisan. Tuturan disebut juga ujaran, yang merupakan sebuah tindakan. Alviah (2014) menyatakan bahwa ujaran mencakup berbagai maksud atau tujuan yang dapat diidentifikasikan dengan mempertimbangkan konteks ujarannya. Dalam setiap tuturan terdapat fitur bahasa yang mencerminkan maksud tuturan tersebut. Jadi tuturan merupakan ujaran yang memiliki fungsi sebagai suatu satuan fungsional dalam komunikasi.

Menurut Searle (dalam Ariyanti \& Zulaeha, 2017) tuturan dibagi menjadi lima jenis yaitu, tutur representatif, direktif, ekspresif, komisif dan deklarasi. Dari berbagai jenis tuturan, peneliti tertarik untuk meneliti tuturan ekspresif. Peneliti 
tertarik karena dengan meneliti tuturan ekspresif seseorang peneliti mengetahui sikap psikologis penutur. Tuturan ekspresif sendiri merupakan tuturan yang menunjukkan atau menyatakan sikap psikologis penutur terhadap suatu keadaan.

Yule (2014) berpendapat bahwa tuturan ekspresif ialah jenis tuturan yang menyatakan sesuatu yang penutur rasakan. Tindak tutur ini mencerminkan pernyataan-pernyataan psikologis penutur terhadap suatu keadaan. Tindak tutur ekspresif merupakan tindakan yang dimaksudkan oleh penutur sebagai penilaian tentang hal yang disebutkan dalam tuturan itu, meliputi tuturan ucapan selamat, terima kasih, mengkritik, mengeluh, menyalahkan, memuji, meminta maaf, dan menyindir (Rohmadi, 2004). Istikoma dan Wijayanti (2020) mengungkapkan bahwa tuturan ekspresif dapat ditemukan dalam berbagai kegiatan, seperti debat. Menurut Widyamartaya (dalam Wiyata, 2013), berdebat berarti berbicara dengan orang lain untuk mengadvokasi atau menyerang pendapatnya, saling beradu kecerdasan dan logika.

Politik debat digunakan sebagai sarana untuk menyampaikan visi, misi, dan program kerja CAPRES (Putri, 2018). Melalui debat terutama sesi tanya jawab, pemilih dapat mengetahui kualitas calon pemimpinnya, baik dari cara bertanya maupun cara menjawabnya. Kegiatan debat akan menghasilkan gagasan yang diungkapkan dalam bentuk tuturan lisan. Bentuk tuturan tersebut dikemas dalam bahasa yang menarik dan memiliki pesan pragmatis. Secara sadar maupun tidak sadar peserta debat tersebut telah melakukan kegiatan berbahasa sebagai penutur dan mitra tutur. Penutur adalah orang yang mengungkapkan fungsi pragmatis tertentu di dalam peristiwa komunikasi. Sedangkan mitra tutur adalah orang yang menjadi lawan penutur di dalam pembicaraan. Seseorang yang awalnya berperan sebagai penutur pada tahap tuturan berikutnya dapat menjadi mitra tutur begitu juga sebaliknya (Wiyata, 2013).

Berdasarkan pernyataan di atas, dapat disimpulkan bahwa semua kegiatan berbahasa yang berupa tuturan memiliki potensi untuk dikaji ke dalam kajian pragmatik. Dalam politik, debat digunakan sebagai sarana untuk menyampaikan visi, misi, dan program kerja CAPRES (Putri, 2018). Melalui debat terutama sesi tanya jawab, pemilih dapat mengetahui kualitas calon pemimpinnya, baik dari cara bertanya maupun cara menjawabnya. Hal ini membuat peneliti tertarik melakukan penelitian terhadap kegiatan berbahasa yaitu debat Calon Preseiden Joko Widodo (Jokowi) dan Prabowo Subianto pada Youtube Channel CNN Indonesia. Berikut ini salah satu data yang ditemukan dalam debat CAPRES RI 2019.

"Saya menghargai niat pak Jokowi dalam memimpin infrastruktur, tetapi saya juga harus menyampaikan kemungkinan besar tim pak Jokowi itu bekerjanya kurang efisien" disampaikan oleh Prabowo (penutur) kepada Jokowi (lawan tutur).

Berdasarkan latar belakang di atas, karena kurangnya pengetahuan masyarakat mengenai fungsi tuturan ekspresif, mengkaji dan mempelajari tuturan ekspresif merupakan hal yang sangat penting. Oleh sebab itu, melalui penelitian akan dikaji pemakaian tuturan ekspresif dalam debat CAPRES RI 2019. Debat CAPRES RI 2019 dipilih sebagai topik kajian penelitian ini karena bagian terpenting dalam pesta demokrasi ialah debat. Pada kesempatan inilah pasangan calon presiden 
menyampaikan visi dan misinya sebagai sarana mendapatkan kepercayaan dari masyarakat. Debat tersebut juga ditonton oleh seluruh masyarakat Indonesia, sehingga tuturan yang digunakan dalam debat tersebut sangat perlu untuk dianalisis untuk mengetahui tujuan dari setiap tuturan yang diucapkan oleh calon Presiden dan wakil Presiden. Selain itu, tuturan ekspresif dalam debat CAPRES RI 2019 belum pernah diteliti. Oleh karena itu, penelitian ini dilakukan dengan tujuan untuk mendeskripsikan fungsi tuturan ekspresif yang digunakan dalam debat CAPRES RI 2019. Selanjutnya manfaat penelitian ini adalah Penelitian ini diharapkan memberi sumbangan teori yang berkaitan dengan tuturan ekspresif.

\section{METODE PENELITIAN}

Metode penelitian pada dasarnya merupakan cara ilmiah untuk mendapatkan data dengan tujuan dan kegunaan tertentu (Sugiyono, 2016). Metode yang digunakan dalam penelitian ini adalah metode deskriptif kualitatif. Arikunto (2014) menyatakan bahwa metode deskriptif kualitatif adalah metode yang digunakan untuk mendeskripsikan apa adanya hasil dari suatu pengumpulan data yang telah dilakukan oleh penulis, serta berupaya memecahkan permasalahan yang dihadapi dengan cara mengumpulkan data, mengklasifikasikan data, menganalisis data, menginterprestasikan hasil analisis, membuat kesimpulan, dan menyusun laporan akhir. Pada penelitian ini peneliti mendeskripsikan fungsi tuturan ekspresif yang terdapat dalam debat CAPRES RI 2019. Data bersumber dari debat CAPRES RI 2019 pada youtube channel CNN Indonesia. Debat CAPRES RI 2019 terdiri dari 5 putaran. Dari kelima debat tersebut peneliti hanya meneliti dua debat, yakni debat kedua dan keempat. Debat kedua tayang pada tanggal 17 Februari 2019 dan debat keempat tayang pada tanggal 30 Maret 2019.

Teknik pengumpulan data yang digunakan dalam penelitian ini adalah teknik simak dan teknik catat. Mahsun (2012) mengemukakan teknik simak ada dua macam yaitu teknik simak bebas libat cakap dan teknik simak libat cakap. Penelitian ini menggunakan teknik simak bebas libat cakap yang bertujuan untuk mendapatkan data dengan cara menyimak percakapan informan, sehingga data yang diperoleh lebih nyata dan tidak dibuat-buat karena informan tidak mengetahui bahwa tuturan bahasannya sedang diteliti. Teknik simak bebas libat cakap ini diikuti dengan teknik lanjut, yaitu teknik catat yang dilakukan ketika menerapkan teknik simak (Mahsun, 2012).

Peneliti melakukan analisis data menggunakan metode padan intralingual, yaitu metode analisis dengan cara menghubung bandingkan unsur-unsur yang bersifat lingual (Mahsun, 2012). Langkah-langkah yang dilakukan dalam menganalisis data penelitian ini adalah sebagai berikut. Pertama, mengubah data ke bentuk teks, yaitu data yang terdapat dalam video dipindahkan ke dalam teks tertulis. Kedua, mengidentifikasi tuturan ekspresif yang terdapat dalam debat CAPRES RI 2019 pada youtube channel CNN Indonesia. Dalam mengidentifikasi digunakan asas analogo (penyesuaian) dan tafsiran lokal (penjelasan pendapat atau pendapat suatu kata, kalimat, dan lain sebagainya) dengan konteks data. Kemudian data tersebut dicatat. Ketiga, mengklasifikasikan data berdasarkan fungsi tuturan ekspresif yang meliputi, tuturan ekspresif mengucapkan selamat, ucapan terima kasih, mengkritik, mengeluh, menyalahkan, memuji, meminta maaf, dan menyindir agar lebih mudah dalam menganalisis data. Keempat, 
menganalisis data yang sudah diklasifikasikan menggunakan teori fungsi tuturan ekspresif menurut Searle dalam debat CAPRES RI 2019. Kelima, menyimpulkan fungsi tuturan ekspresif yang terdapat dalam debat CAPRES RI 2019 pada youtube channel CNN Indonesia.

\section{HASIL DAN PEMBAHASAN}

Alviah (2014) mengatakan tuturan mengandung beragam maksud yang dapat diidentifikasikan dengan mempertimbangkan konteks tuturannya. Di balik suatu tuturan terdapat fungsi bahasa yang tercermin dalam maksud tuturan tersebut. Menurut Searle (dalam Ariyanti \& Zulaeha, 2017) tuturan dibagi menjadi lima jenis yaitu, tutur representatif, direktif, ekspresif, komisif dan deklarasi. Dari berbagai jenis tuturan, pada penelitian ini akan dibahas tuturan ekspresif. Searle (dalam Rohmadi, 2004:32) menyatakan bahwa tindak tutur ekspresif merupakan tindakan yang dimaksudkan oleh penutur sebagai penilaian tentang hal yang disebutkan dalam tuturan itu, meliputi tuturan mengucapkan terima kasih, mengeluh, mengucapkan selamat, meminta maaf, memuji, menyalahkan, menyindir, dan mengkritik. Berdasarkan hasil penelitian, tuturan ekspresif yang terdapat dalam debat CAPRES Republik Indonesia 2019 berjumlah 81 data tuturan yaitu ucapan selamat berjumlah 6 data tuturan, terima kasih berjumlah 32 data tuturan, mengkritik berjumlah 12 data tuturan, mengeluh berjumlah 3 data tuturan, menyalahkan berjumlah 9 data tuturan, memuji berjumlah 1 data tuturan, meminta maaf 9 data tuturan, dan menyindir berjumlah 9 data tuturan. Adapun rincian penjelasannya ialah sebagai berikut.

\section{Fungsi Tuturan Ekspresif Mengucapkan Selamat}

Tuturan ekspresif mengucapkan selamat berfungsi sebagai bentuk apresiasi dan rasa senang atas keberhasilan. Ucapan selamat bisa juga digunakan sebagai salam pembuka dalam sebuah acara ataupun bisa digunakan untuk menyapa seseorang. Mengucapkan salam juga sebagai perbuatan yang terpuji karena didalamnya berisi doa. Berikut ini adalah contoh fungsi tuturan ekspresif mengucapkan selamat.

"Bismillahirohmanirohim. Assalamualaikum warahmatullah wabarakatuh. Selamat malam. Salam sejahtera buat kita semuanya. Om Swastiastu. nama buddhaya salam kebajikan. Yang saya hormati ketua KPU beserta komisioner, ketua bawaslu, staf komisioner, yang saya hormati sahabat baik saya Bapak Prabowo Subianto, seluruh rakyat Indonesia yang saya cintai. visi kami adalah Indonesia maju, di bidang energi kedepan kita ingin sebanyakbanyaknya mengurangi pemakaian energi fosil." Disampaikan oleh Jokowi (penutur) kepada lawan tutur.

Tuturan di atas merupakan tuturan ekspresif dengan fungsi mengucapkan selamat. Tuturan tersebut berlangsung ketika Jokowi (penutur) menyampaikan visi misi. Topik yang dibahas dalam tuturan tersebut ialah mengutarakan visi misi masing-masing calon Presiden. Penutur bermaksud menyapa para hadirin yang telah hadir sekaligus sebagai salam pembuka penyampaian visi misi. Tuturan diucapkan dengan intonasi yang sedang dan suasana yang serius. Berdasarkan konteks tuturan, data tersebut termasuk fungsi tuturan ekspresif mengucapkan 
selamat yang ditandai pada kalimat "Selamat malam. Salam sejahtera buat kita semuanya."

\section{Tuturan Ekspresif Ucapan Terima Kasih}

Tuturan eskpresif mengucapkan terima kasih berfungsi sebagai wujud ucapan rasa syukur terhadap orang yang sudah memberi kebaikan dan sebagainya. Ucapan terima kasih juga dipakai untuk menutup sebuah pembicaraan yang berfungsi sebagai ucapan syukur karena sudah diberikan kesempatan untuk berbicara. Berikut adalah contoh fungsi tuturan ekspresif ucapan terima kasih.

"Baik, terima kasih Bapak Prabowo Subianto waktunya sudah habis. Cukup Bapak waktunya sudah habis. Terima kasih. Silakan duduk kembali." Disampaikan oleh Moderator (penutur) kepada lawan tutur.

Tuturan di atas merupakan tuturan ekspresif dengan fungsi ucapan terima kasih. Tuturan tersebut berlangsung ketika Moderator (penutur) mengingatkan lawan tutur kalau waktu yang diberikan sudah habis dengan mengucapkan terima kasih sebagai bentuk menghormati dan menghargai lawan tutur. Topik yang dibahas dalam tuturan tersebut ialah pergantian waktu berbicara. Penutur bermaksud mengucapkan terima kasih kepada Bapak Prabowo (lawan tutur) yang telah menanggapi pernyataan Pak Jokowi. Tuturan diucapkan dengan intonasi suara yang sedang dan suasana yang serius. Berdasarkan konteks tuturan, data tersebut termasuk fungsi tuturan ekspresif ucapan terima kasih yang ditandai pada kalimat "terima kasih Bapak Prabowo."

\section{Fungsi Tuturan Ekspresif Mengkritik}

Fungsi tuturan ekspresif mengkritik ditandai dengan adanya tuturan dari penutur berupa kritik atau tanggapan yang disertai dengan penjelasan yang baik atau buruk terhadap suatu karya, pendapat, tindakan dan sebagainya. Mengkritik berfungsi sebagai evaluasi bagi mitra tuturnya agar lebih baik lagi. Berikut adalah contoh tuturan ekspresif mengkritik.

"Saya menghargai niat pak Jokowi dalam memimpin pembangunan infrastruktur tetapi saya juga harus menyampaikan kemungkinan besar tim Pak Jokowi itu bekerjanya kurang efisien, banyak infrastruktur yang dikerjakan dilaksanakan dengan grusa-grusu tanpa feasibility study yang benar, dan ini mengakibatkan banyak proyek infrastruktur yang tidak efisien yang rugi, bahkan yang sangat sangat sulit untuk dibayar." Disampaikan oleh Prabowo (penutur) kepada lawan tutur.

Tuturan di atas merupakan tuturan ekspresif dengan fungsi mengkritik. Tuturan tersebut berlangsung ketika Pabowo (penutur) mengkritik lawan tutur. Topik yang dibahas dalam tuturan tersebut ialah Infrastruktur. Penutur bermaksud untuk mengkritik cara kerja lawan tutur yang kurang efesien sehingga banyak proyek infrastruktur yang tidak efisien bahkan mengalami kerugian. Tuturan diucapkan dengan intonasi yang agak tinggi dan suasana yang serius. Berdasarkan konteks tuturan, data tersebut termasuk fungsi tuturan ekspresif mengkritik yang 
ditandai pada kalimat "kemungkinan besar tim pak Jokowi itu bekerjanya kurang efisien".

"Menteri kehutanan kok dijadikan satu sama lingkungan hidup yang satu KLH harus mengawasi menteri Departemen Kehutanan kok jadi satu, jadi ini segera akan kita pisahkan sehingga KLH akan benar-benar menegakkan masalah lingkungan hidup tidak jadi satu ya ini sering menjadi masalah kemudian juga izin-izin akan kita perketat AMDAL harus dilaksanakan tidak ada jalan jalan pintas untuk ke AMDAL yang sangat cepat sering secara legal seperti tadi tapi kadang-kadang itu etok-etok AMDAL yang etok-etok." Disampaikan oleh Prabowo (penutur) kepada lawan tutur.

Tuturan di atas merupakan tuturan ekspresif dengan fungsi mengkritik. Tuturan tersebut berlangsung ketika Pabowo (penutur) mengkritik menteri kehutanan yang dijadikan satu dengan lingkungan hidup. Topik yang dibahas dalam tuturan tersebut ialah sumber daya alam dan lingkungan hidup. Penutur bermaksud mengkritik kementerian pada masa pimpinan Pak Jokowi yang menjadikan menteri lingkungan hidup dan kehutanan menjadi satu. Penutur menginginkan menteri lingkungan hidup dan kehutanan itu dipisah jangan dijadikan satu. Tuturan diucapkan dengan intonasi yang agak tinggi dan suasana yang serius. Berdasarkan konteks tuturan, data tersebut termasuk fungsi tuturan ekspresif mengkritik yang ditandai pada kalimat "Menteri kehutanan kok dijadikan satu sama lingkungan hidup".

\section{Fungsi Tuturan Ekspresif Mengeluh}

Tuturan ekspresif mengeluh berfungsi sebagai wujud ketidak sanggupan, kesusahan atau kesulitan. Mengeluh juga digunakan saat seseorang merasakan kecewa terhadap perilaku atau pekerjaan orang lain, disaat merasakan kesakitan dan penderitaan. Berikut adalah contoh tuturan ekspresif mengeluh.

"Jadi semua teknologi, semua system itu baik, tetapi kita harus, kita harus sepakat kalu kita sakit, kita harus berani menghadapi penyakit kita, kalau kita sakit liver ya sakit liver ya kita obati. Penyakit bangsa ini korupsi terlalu banyak. Rakyat tidak mau lagi korupsi di Indonesia." Disampaikan oleh Prabowo (penutur) kepada lawan tutur.

Tuturan di atas merupakan tuturan ekspresif dengan fungsi mengeluh. Tuturan tersebut berlangsung ketika Pabowo (penutur) merasa kalau korupsi di Indonesia sudah terlalu banyak dan harus diberantas. Topik yang dibahas dalam tuturan tersebut ialah banyaknya korupsi di Indonesia. Penutur merasa kesusahan atau kesulitan dalam memberantas korupsi karena korupsi di Indonesia sudah terlalu banyak, sehingga sulit untuk diatasi. Tuturan diucapkan dengan intonasi suara yang sedang dan suasana yang serius. Berdasarkan konteks tuturan, data tersebut termasuk fungsi tuturan ekspresif mengeluh yang ditandai pada kalimat "Penyakit bangsa ini korupsi terlalu banyak. Rakyat tidak mau lagi korupsi lagi di Indonesia”. 
"Tetapi saya kembali menganggap ada hal yang mungkin Bapak tidak merasakan, bahwa sebenarnya kita tidak terlalu dihormati Pak, di luar Indonesia kita tidak dihormati karena mereka tahu Indonesia ini ya selalu utang banyak, mata uang lemah." Disampaikan oleh Prabowo (penutur) kepada lawan tutur.

Tuturan di atas merupakan tuturan ekspresif dengan fungsi mengeluh. Tuturan tersebut berlangsung ketika Pabowo (penutur) merasa di luar Indonesia kita tidak dihormati. Topik yang dibahas dalam tuturan tersebut ialah Indonesia tidak dihormati karena mempunyai banyak hutang dan mata uang lemah. Penutur merasa kesusahan dan merasa Indonesia tidak dihormati oleh Negara lain karena Indonesia mempunyai banyak hutang dan mata uang Indonesia juga lemah. Tuturan diucapkan dengan intonasi suara yang sedang dan suasana yang serius. Berdasarkan konteks tuturan, data tersebut termasuk fungsi tuturan ekspresif mengeluh yang ditandai pada kalimat "di luar Indonesia kita tidak dihormati karena mereka tahu Indonesia ini ya selalu utang banyak, mata uang lemah".

\section{Fungsi Tuturan Ekspresif Menyalahkan}

Tuturan ekspresif menyalahkan berfungsi sebagai wujud ungkapan yang menganggap orang lain melakukan sebuah kesalahan atas perbuatan atau pekerjaannya. Berikut adalah contoh tuturan ekspresif fungsi menyalahkan.

"Ya kalau tadi pak prabowo menyampaikan tanpa feasibility study tadi saya kira salah besar, karena ini sudah direncanakan lama, ini sudah direncanakan lama tentu saja semuanya ada." Disampaikan oleh Jokowi (penutur) kepada lawan tutur.

Tuturan di atas merupakan tuturan ekspresif dengan fungsi menyalahkan. Tuturan tersebut berlangsung ketika Jokowi (penutur) merasa pendapat Prabowo (lawan tutur) itu salah. Topik yang dibahas dalam tuturan tersebut ialah pembangunan infrastruktur. Penutur bermaksud menyalahkan pendapat lawan tutur yang mengatakan dalam membangun infrastruktur tim Pak Jokowi bekerjanya kurang efisien dan tanpa feasibility study yang benar. Penutur menyampaikan bahwa semuanya sudah direncanakan lama dan tentu semuanya sudah dengan feasibility study yang benar. Tuturan diucapkan dengan intonasi suara yang sedang dan suasana yang serius. Berdasarkan konteks tuturan, data tersebut termasuk fungsi tuturan ekspresif menyalahkan yang ditandai pada kalimat "Ya kalau tadi pak prabowo menyampaikan tanpa feasibility study tadi saya kira salah besar".

"Sebetulnya kalau pembangunan infastruktur untuk rakyat, tadi di depan sudah saya sampaikan Pembangunan $191.000 \mathrm{~km}$ jalan-jalan di desa itu adalah betul-betul untuk rakyat di bawah. Ini yang sering tidak dilihat orang, kemudian untuk ganti rugi mungkin Pak Prabowo bisa lihat dalam 4 setengah tahun ini hampir tidak ada terjadi konflik pembebasan lahan untuk infrastruktur kita, karena apa, tidak ada ganti rugi yang ada ganti untung." Disampaikan oleh Jokowi (penutur) kepada lawan tutur. 
Tuturan di atas merupakan tuturan ekspresif dengan fungsi menyalahkan. Tuturan tersebut berlangsung ketika Jokowi (penutur) menanggapi pernyataan lawan tutur. Topik yang dibahas dalam tuturan tersebut ialah pembangunan infrastruktur. Penutur bermaksud menyalahkan pendapat Pak Prabowo (lawan tutur) yang mengatakan kalau negara harus membayar biaya untuk ganti rugi kepada masyarakat yang tanahnya diambil tanpa ada penyaluran pengalihan kehidupan mereka. Tuturan diucapkan dengan intonasi suara yang sedang dan suasana yang serius. Berdasarkan konteks tuturan, data tersebut termasuk fungsi tuturan ekspresif menyalahkan yang ditandai pada kalimat "tidak ada ganti rugi yang ada ganti untung”.

\section{Fungsi Tuturan Ekspresif Memuji}

Tuturan memuji berfungsi sebagai ungkapan menyenangkan kepada lawan tuturnya. Fungsi memuji sebagai wujud untuk memberi rasa senang kepada lawan tuturnya dengan melebih-lebihkan kepada lawan tuturnya. Misalnya tentang kebaikannya, kedermawanannya, kecantikannya, dan lain sebagainya. Berikut ini adalah contoh fungsi tuturan ekspresif memuji.

"Yang saya hormati sahabat baik saya Bapak Prabowo Subianto, seluruh rakyat Indonesia yang saya cintai. Visi Kami adalah Indonesia maju di bidang energi kedepan kita ingin sebanyak-banyaknya mengurangi pemakaian energi fosil." Disampaikan oleh Jokowi (penutur) kepada lawan tutur.

Tuturan di atas merupakan tuturan ekspresif dengan fungsi memuji. Tuturan tersebut berlangsung ketika Jokowi (penutur) menyapa Prabowo (lawan tutur) sebagai sahabat baiknya. Topik yang dibahas dalam tuturan tersebut ialah penyampaian visi misi. Penutur merasa senang dan memuji lawan tutur dengan menyebut Pak Prabowo sebagai sahabat baik dihadapan publik. Tuturan diucapkan dengan intonasi yang sedang dan suasana yang serius. Berdasarkan konteks tuturan, data tersebut termasuk fungsi tuturan ekspresif memuji yang ditandai pada kalimat "Sahabat baik saya".

\section{Fungsi Tuturan Ekspresif Meminta Maaf}

Tuturan ekspresif meminta maaf berfungsi sebagai wujud pengakuan ketika melakukan kesalahan dan belajar dari kesalahan tersebut. Meminta maaf biasanya dilakukan atas kesalahan yang telah diperbuat, meminta maaf juga sebagai bentuk rasa sopan ketika bertanya, atau permintaan ijin melakukan sesuatu. Berikut adalah contoh tuturan ekspresif meminta maaf.

"Jadi masalah pertahanan keamanan ini saya kira maaf Pak Jokowi mungkin Pak Jokowi dapat brising-brising yang kurang tepat.” Disampaikan oleh Prabowo (penutur) kepada lawan tutur.

Tuturan di atas merupakan tuturan ekspresif dengan fungsi meminta maaf. Tuturan tersebut berlangsung ketika Prabowo (penutur) menanggapi pernyataan Jokowi (lawan tutur). Topik yang dibahas dalam tuturan tersebut ialah pertahanan dan keamanan Indonesia. Penutur bermaksud meminta maaf kepada Bapak Jokowi (lawan tutur) agar lawan tutur tidak tersinggung dengan ucapan penutur. 
Tuturan diucapkan dengan intonasi yang sedang dan suasana yang serius. Berdasarkan konteks tuturan, data tersebut termasuk fungsi tuturan ekspresif maaf yang ditandai pada kalimat "maaf Pak Jokowi".

"Kadang-kadang maaf Pak suara saya keras, saya ini setengah banyumas setengah Minahasa Pak, Bapakkan solo, halus, jadi kalau, kalau banyumas ini apa itu bataknya orang jawa." Disampaikan oleh Prabowo (penutur) kepada lawan tutur.

Tuturan di atas merupakan tuturan ekspresif dengan fungsi meminta maaf. Tuturan tersebut berlangsung ketika Pabowo (penutur) menanggapi pernyataan Jokowi (lawan tutur). Topik yang dibahas dalam tuturan tersebut ialah suku masing-masing calon presiden. Penutur bermaksud meminta maaf kepada Bapak Jokowi (lawan tutur) karena penutur merasa sering menggunakan suara yang keras ketika berbicara, sekaligus sebagai tanda kalau penutur menghormati lawan tutur. Tuturan diucapkan dengan intonasi yang sedang dan suasana yang santai. Berdasarkan konteks tuturan, data tersebut termasuk fungsi tuturan ekspresif maaf yang ditandai pada kalimat "maaf Pak".

\section{Fungsi Tuturan Ekspresif Menyindir}

Tuturan ekspresif menyindir berfungsi sebagai menyatakan sesuatu seperti celaan dan ejekan secara tidak langsung. Menyindir biasanya dilakukan untuk mengejek atau mencela seseorang tetapi dalam menyampaikan tidak terus terang. Berikut adalah contoh tuturan ekspresif menyindir.

"Saya berpandangan bahwa korupsi di Indonesia sudah dalam taraf yang sangat parah, kalau penyakit saya kira ini sudah sampai stadium 4 dan rakyat-rakyat yang saya temui di Indonesia tidak mau negara ini terus seperti ini, mereka ingin negara dengan pemerintahan yang tidak korup." Disampaikan oleh Prabowo (penutur) kepada lawan tutur.

Tuturan di atas merupakan tuturan ekspresif dengan fungsi menyindir. Tuturan tersebut berlangsung ketika Prabowo (penutur) menyampaikan pernyataannya. Topik yang dibahas dalam tuturan tersebut ialah korupsi di Indonesia sudah dalam taraf yang sangat parah. Penutur bermaksud menyindir bahwa dalam pemerintahan Pak Jokowi sangat banyak pejabat yang korupsi dan hal itu tidak diinginkan oleh masyarakat Indonesia. Tuturan diucapkan dengan intonasi yang agak tinggi dan suasana yang serius. Berdasarkan konteks tuturan, data tersebut termasuk fungsi tuturan ekspresif menyindir yang ditandai pada kalimat "korupsi di Indonesia sudah dalam taraf yang sangat parah, kalau penyakit saya kira ini sudah sampai stadium 4 ".

"Inti masalahnya Pak Jokowi, saya ini memang profesi saya, bidang saya adalah pertahanan keamanan, saya pelajari ilmu perang ribuan tahun, sejarah perang saya pelajari, teknologi saya masih kuasai Pak, saya tahu jarak-jarak peluru kendali masih saya tau. Jadi saya mohon Pak ini bukan menyalahkan tapi saya, saya berpendapat kekuatan pertahanan kita sangat 
rapuh dan lemah bukan salah Bapak, salah, ngak tahu saya." Disampaikan oleh Prabowo (penutur) kepada lawan tutur.

Tuturan di atas merupakan tuturan ekspresif dengan fungsi menyindir. Tuturan tersebut berlangsung ketika Prabowo (penutur) menanggapi pernyataan dari lawan tutur. Topik yang dibahas dalam tuturan tersebut ialah pertahanan dan keamanan Indonesia. Penutur bermaksud menyindir Pak Jokowi yang menjadi penyebab lemahnya kekuatan pertahanan di Indonesia, tetapi penutur tidak menyampaikannya secara langsung. Tuturan diucapkan dengan intonasi yang agak tinggi dan suasana yang serius. Berdasarkan konteks tuturan, data tersebut termasuk fungsi tuturan ekspresif menyindir yang ditandai pada kalimat "saya berpendapat kekuatan pertahanan kita sangat rapuh dan lemah bukan salah Bapak, salah, ngak tahu saya".

Berdasarkan analisis data, tuturan ekspresif yang muncul dalam debat CAPRES Republik Indonesia 2019 terdapat delapan fungsi tuturan ekspresif yaitu, ucapan selamat, terima kasih, mengkritik, mengeluh, menyalahkan, memuji, meminta maaf, dan menyindir. Hal ini sesuai dengan yang dikemukakan oleh Searle (dalam Rohmadi, 2004). Fungsi tuturan ekspresif dalam debat CAPRES Republik Indonesia 2019 terdapat 81 data tuturan, yaitu ucapan selamat berjumlah 6 data tuturan, terima kasih berjumlah 32 data tuturan, mengkritik berjumlah 12 data tuturan, mengeluh berjumlah 3 data tuturan, menyalahkan berjumlah 9 data tuturan, memuji berjumlah 1 data tuturan, meminta maaf 9 data tuturan, dan menyindir berjumlah 9 data tuturan.

Pada penelitian tuturan ekspresif dalam debat CAPRES RI 2019 tuturan ekspresif yang dominan ialah tuturan ekspresif ucapan terima kasih. Tuturan ekspresif ucapan terima kasih paling dominan, hal itu disebabkan oleh mitra tutur menghargai dan menghormati lawan tutur selain itu juga, hal tersebut disebabkan karena para peserta debat merupakan orang yang berpendidikan tinggi dan sebagai calon pemimpin bangsa yang tentunya mempunyai retorika yang baik. Hal tersebut sejalan dengan pendapat Allen (dalam Syaifudin, 2005) ungkapan terima kasih dalam komunikasi sehari-hari adalah salah satu contoh dari banyak strategi kesopanan yang digunakan manusia dalam rangka memupuk dan memelihara hubungan sosial. Hal tersebut juga didukung oleh Boangmanalu dan Lumbangaol (2015) kata terima kasih mengandung nilai kesantunan sebagai sikap hormat terutama kepada lawan tutur yang kedudukannya dalam tataran lebih tinggi atau setara.

Searle (dalam Rohmadi, 2004) menyatakan bahwa tindak tutur ekspresif merupakan tindakan yang dimaksudkan oleh penutur sebagai penilaian tentang hal yang disebutkan dalam tuturan itu. Penggunaan tuturan ekspresif ucapan selamat berfungsi sebagai bentuk apresiasi dan rasa senang atas keberhasilan. Ucapan selamat bisa juga digunakan sebagai salam pembuka dalam sebuah acara ataupun bisa digunakan untuk menyapa seseorang. Dalam debat ini tuturan tersebut digunakan sebagai salam pembuka sekaligus menyapa para penonton baik itu yang disampaikan oleh moderator ataupun oleh peserta debat.

Penggunaan tuturan eskpresif mengucapkan terima kasih berfungsi sebagai wujud ucapan rasa syukur terhadap orang yang sudah memberi kebaikan dan sebagainya. Ucapan terima kasih juga dipakai untuk menutup sebuah pembicaraan yang berfungsi sebagai ucapan syukur karena sudah diberikan kesempatan untuk 
berbicara. Dalam debat ini tuturan ucapan terima kasih digunakan sebagai bentuk sopan santun sekaligus menghormati dan menghargai lawan tutur. Ucapan terima kasih tersebut disampaikan oleh moderator dan para calon presiden.

Penggunaan fungsi tuturan ekspresif mengkritik ditandai dengan adanya tuturan dari penutur yang berupa kecaman atau tanggapan disertai dengan penjelasan yang baik atau buruk terhadap suatu hasil karya, pendapat, tindakan dan sebagainya. Mengkritik berfungsi sebagai evaluasi bagi mitra tuturnya agar lebih baik lagi. Dalam debat ini tuturan ekspresif mengkritik disampaikan oleh penutur kepada lawan tutur dengan tujuan menjatuhkan dan membuat penonton mengurangi rasa kepercayaannya terhadap lawan tutur yang dikritik.

Penggunaan tuturan ekspresif mengeluh berfungsi sebagai wujud ketidak sanggupan, kesusahan atau kesulitan. Mengeluh juga digunakan saat seseorang merasakan kecewa terhadap perilaku atau pekerjaan orang lain, disaat merasakan kesakitan dan penderitaan. Dalam debat ini tuturan ekspresif mengeluh disampaikan oleh penutur kepada lawan tutur untuk menyampaikan keluh kesah yang selama ini membuatnya merasa kecewa. Hal itu ditandai dengan tuturan yang disampaikan oleh Prabowo (penutur) kepada Jokowi (lawan tutur) yang kecewa terhadap kinerja tim Jokowi.

Penggunaan tuturan ekspresif menyalahkan berfungsi sebagai wujud ungkapan yang menganggap orang lain melakukan sebuah kesalahan atas perbuatan atau pekerjaannya. Dalam debat ini tuturan ekspresif menyalahkan disampaikan oleh penutur kepada lawan tutur dengan tujuan menjatuhkan lawan tutur sekaligus meningkatkan kredibilitas penutur.

Tuturan memuji berfungsi sebagai ungkapan menyenangkan kepada lawan tuturnya. Fungsi memuji sebagai wujud untuk memberi rasa senang kepada lawan tuturnya dengan melebih-lebihkan kepada lawan tuturnya. Misalnya tentang kebaikannya, kedermawanannya, kecantikannya, dan lain sebagainya. Dalam debat ini tuturan ekspresif disampaikan oleh penutur untuk memuji kebaikan lawan tutur sekaligus memberikan rasa senang kepada lawan tutur.

Tuturan ekspresif meminta maaf berfungsi sebagai wujud pengakuan ketika melakukan kesalahan dan belajar dari kesalahan tersebut. Meminta maaf biasanya dilakukan atas kesalahan yang telah diperbuat, meminta maaf juga sebagai bentuk rasa sopan ketika bertanya, atau permintaan ijin melakukan sesuatu. Dalam debat ini tuturan ekspresif meminta maaf digunakan sebagai bentuk sopan ketika memotong pembicaraan lawan tutur dan juga sebagai bentuk permohonan maaf ketika melakukan kesalahan.

Tuturan ekspresif menyindir berfungsi sebagai menyatakan sesuatu seperti celaan dan ejekan secara tidak langsung. Menyindir biasanya dilakukan untuk mengejek atau mencela seseorang tetapi dalam menyampaikan tidak terus terang. Dalam debat ini tuturan ekspresif menyindir disampaikan dengan tujuan membuat lawan tutur menyadari kesalahan-kesalahan yang telah dilakukan.

\section{SIMPULAN}

Berdasarkan analisis data pada fungsi tuturan ekspresif dalam debat CAPRES Republik Indonesia 2019, maka dapat disimpulkan fungsi tuturan ekspresif dibagi menjadi delapan, yaitu tuturan ekspresif mengucapkan terima kasih, mengeluh, mengucapkan selamat, meminta maaf, memuji, menyalahkan, menyindir, dan 
mengkritik. Dari hasil penelitian tuturan ekspresif dalam debat CAPRES Republik Indonesia 2019 terdapat 81 data tuturan, yaitu ucapan selamat berjumlah 6 data tuturan, terima kasih berjumlah 32 data tuturan, mengkritik berjumlah 12 data tuturan, mengeluh berjumlah 3 data tuturan, menyalahkan berjumlah 9 data tuturan, memuji berjumlah 1 data tuturan, meminta maaf 9 data tuturan, dan menyindir berjumlah 9 data tuturan.

\section{REFERENSI}

Alviah, I. (2014). Kesantunan berbahasa dalam tuturan novel Para Priyayi karya Umar Kayam. Seloka: Jurnal Pendidikan Bahasa dan Sastra Indonesia, 3(2), 128-135. https://doi.org/10.15294/seloka.v3i2.6629.

Arikunto, S. (2014). Prosedur Penelitian Suatu Pendekatan Praktik. Rineka Cipta.

Ariyanti, L. D., \& Zulaeha, I. (2017). Tindak tutur ekspresif humanis dalam interaksi pembelajaran di sma negeri 1 batang: Analisis wacana kelas. Seloka: Jurnal Pendidikan Bahasa dan Sastra Indonesia,6(2), 111-122. https://doi.org/10.15294/seloka.v6i2.17272

Boangmanalu, I. A., \& Lumbangaol, G. (2014). Penggunaan Kata Maaf dan Terimakasih: Kesantunan Berbahasa Bahasa Batak Toba. Prosiding PRASASTI, 368-371.

Chaer, A. (2010). Kesantunan Berbahasa. Rineka Cipta.

CNN Indonesia. (2019, February 19). Full Debat Kedua Capres 2019, Joko Widodo dan Prabowo Subianto [Video]. YouTube. https://www.youtube.com/watch?v=Ck4gJyO4GMc

Indrawati, S. (2018). Menyikapi penggunaan bahasa di facebook: pemerkayaan atau perusakan bahasa Indonesia. In Seminar Bahasa dan Sastra Indonesia (Vol. 1, No. 1, pp. 43-51).

Istikoma, N. A. (2020, January). Bentuk tindak tutur ekspresif dan komisif dalam debat cawapres pilpres 2019 putaran ke-3. In Seminar Nasional SAGA\# 2 (Sastra, Pedagogik, dan Bahasa) (Vol. 2, No. 2, pp. 23-28).

Mahsun. (2012). Metode Penelitian Bahasa. Raja Grafindo Persada

Putri, R. (2018). Tindak Tutur Persuasif Debat Calon Gubernur DKI Jakarta 2018 Putaran Pertama Pada Media Televisi. Simki-Pedagogia, 2(6), 2-9.

Rohmadi, M. (2004). Pragmatik: Teori dan Analisis. Lingkar Media.

Saripudin, A. (2018). Berbahasa dan Berkarakter: Suatu Upaya Pendidikan. Logat: Jurnal Bahasan Indonesia dan Pembelajaran, 1(2), 75-82

Sugiyono. (2016). Metode Penelitian Kombinasi. Alfabeta.

Syaifudin, A. (2005). Faktor Sosial Budaya dan Kesopanan Orang Jepang dalam Pengungkapan Tindak Tutur Terima Kasih pada Skenario Drama Televisi Beautiful Life Karya Kitagawa Eriko (Publication No. T15217) [Master Degree Thesis, Universitas Indonesia]. Universitas Indonesia Library.

Wiyata, A. Y. (2013). Tindak tutur ekspresif pada debat calon gubernur pemilukada DKI Jakarta 2012 putaran ke-2 di METRO TV (Publication No. 22587) [Undergraduate thesis, Universitas Muhammadiyah Surakarta]. Institutional Repository.

Yule, G. (2014). Pragmatik. Pustaka Pelajar. 